\title{
SELECTIVE FORMATION OF LINEAR ALPHA-OLEFINS VIA MICROWAVE CATALYTIC CRACKING OF STRAIGHT-CHAIN ALKANES
}

\author{
V.A. Bolotov ${ }^{1}$, S.F. Tikhov ${ }^{1}$, K.R. Valeev ${ }^{1}$, V.T. Shamirzaev ${ }^{1}$, V.N. Parmon ${ }^{1,2}$ \\ ${ }^{1}$ Boreskov Institute of Catalysis, Siberian Branch, Russian Academy of Sciences, \\ pr. Lavrentieva 5, 630090, Novosibirsk, Russia \\ ${ }^{2}$ Novosibirsk National Research State University, Novosibirsk-90, 2 Pirogova Str., 630090, \\ Novosibirsk, Russia
}

bolotov@catalysis.ru

Keywords: microwave heating, catalyst, linear alpha-olefins

\section{Introduction}

Linear even-carbon-number alpha-olefins (LAO) with four or more carbon atoms are important compounds of high demand in chemical industry as precursors of a wide range of value-added chemicals [1]. The linear alpha-olefins are used as co-monomers for polyethylene production, for the production of alcohols (mainly in detergents and plasticizers) and for synthesis of polyalphaolefins (used in synthetic lubricants). Butene-1, hexene-1, octene-1 and decene-1 are mainly used to produce high-density polyethylene (HDPE), linear low-density polyethylene (LLDPE) and poly(vinyl chloride) (PVC) plasticizers to impart the stress-crack resistance. $\mathrm{C}_{10}-\mathrm{C}_{14}$ alpha olefins can be used to synthesize linear alkylbenzene (LAB) sulfonates (detergents). Synthetic detergents produced from LAO have enhanced biodegradation characteristics. A conventional route to produce alpha olefins is oligomerization of ethylene, when thermal cracking of naphtha mainly to low-molecular weight paraffin gases is followed by their dehydrogenation to produce low-molecular olefins, the latter being converted to larger alpha olefin molecules through oligomerization. The process provides production of high quality alpha-olefins but is very costly. If not oligomerization, linear alpha-olefins can be produced by thermal cracking of waxy paraffins but the product is not pure and contains numerous internal olefins, dienes and paraffin impurities. The process is conducted in the vapor phase at relatively low cracking temperatures and needs rapid quenching to prevent side reactions such as isomerization or cyclization.

In our previous work [2], we showed that the selectivity to alpha-olefins one can increase considerably via catalytic cracking of n-alkanes under selective MW heating of catalysts. The observed phenomena can be accounted for by an efficient "quenching" of target cracking products via inhibiting undesirable side reactions in the "cold" liquid phase.

In the present work, some general regularities (effect of the temperature, particle size and the morphology of catalyst) of the MW cracking of liquid n-alkanes are presented. Porous composite ceramic matrix $\mathrm{Al}_{2} \mathrm{O}_{3} / \mathrm{Al}$ (ceramometals) and various carbon materials $(\mathrm{CM})$ were studied as supports and precursors of the catalysts. The MW cracking was conducted with n-hexadecane $\mathrm{C}_{16} \mathrm{H}_{34}$ and n-octacosane $\mathrm{C}_{28} \mathrm{H}_{58}$. The influence of the morphology of ceramometals and carbon materials on the structural and group composition of the products was studied.

\section{Experimental}

The MW cracking of high-molecular hydrocarbons was achieved using model straight-chain systems: $99 \%$ n-hexadecane $\mathrm{C}_{16} \mathrm{H}_{34}$ (Acros) (density $0.773 \mathrm{~g} / \mathrm{cm}^{3}$, b.p. $286.5^{\circ} \mathrm{C}$ ) and 99.5 $\%$ n-octacosane $\mathrm{C}_{28} \mathrm{H}_{58}$ (Acros) (density $0.8067 \mathrm{~g} / \mathrm{cm}^{3}$, b.p. $432{ }^{\circ} \mathrm{C}$ ). The $\mathrm{MW}$ cracking was 
carried out using a lab scale set up (operating frequency $2470 \pm 10 \mathrm{MHz}$, power up to $1 \mathrm{~kW}$ ) based on a rectangular single-mode cavity with high Q-factor $(\sim 6000)$, which is excited by oscillation mode $\mathrm{TE}_{102}$, described in [3]. The MW cracking was studied using a non-flow quartz reactor.

The effective heating was provided by introducing to reaction volume various carbon materials $(\mathrm{CM})$ and porous composite ceramic matrix $\mathrm{Al}_{2} \mathrm{O}_{3} / \mathrm{Al}$ (ceramometals) having high dielectric losses. Mesoporous carbon material Sibunit (produced at the Institute for Hydrocarbon Processing, Russia) and carbon nanotubes (CNTs) were used. CNTs were obtained on an $\mathrm{Fe}-\mathrm{Mo}-\mathrm{Co} / \mathrm{Al}_{2} \mathrm{O}_{3}$ catalyst from a propane - butane mixture at $700^{\circ} \mathrm{C}$. The CNT length reached $10^{4} \mathrm{~nm}$, and the outer diameter of CNTs was within $7-26 \mathrm{~nm}$, the dimension of internal channels was within $4-12 \mathrm{~nm}$. Ceramometals were synthesized through the hydrothermal oxidation (HTO) of aluminum powder according to a published procedure [4]. The samples were mixed with paraffin's at the weight ratio paraffin: Sibunit(ceramometals) $=6: 1$; paraffin $:$ CNTs $=15: 1$. The morphology was varied by crushing the initial granules followed by fractioning; in some cases the CM surface was modified by depositing a thin layer of amorphous silica by the method described elsewhere [5]. An industrial catalyst for hydrocarbon cracking (from GASPROMNEFT - Omsk Refinery) was used as the reference sample. The samples under study were heated selectively during MW cracking; MW power was varied to maintain the hydrocarbon temperature close to the boiling point, i.e. the process occurred in the liquid phase.

Experimental efficiency of the conversion of the MW energy to reagent heating was determined by the method suggested elsewhere [6]. The parameters were measured directly in the MW reactor at room temperature and MW power of $1 \mathrm{~mW}$.

\section{Results and discussion}

Table 1 shows morphological properties of samples and maximal efficiencies $\eta_{\max }$ of MW heating obtained at the used MW set up, as well as operational efficiencies $\eta$ of $0.5 \mathrm{~g}$ (in case CNTs $-0.2 \mathrm{~g}$ ) samples observed during MW cracking.

Table 1. Properties of samples under study

\begin{tabular}{|c|c|c|c|c|c|c|c|}
\hline No. & Composition & $\begin{array}{l}\text { Fractional } \\
\text { composition }\end{array}$ & $\begin{array}{l}\mathrm{S}_{\mathrm{BET}} \\
\mathrm{m}^{2} / \mathrm{g}\end{array}$ & $\begin{array}{c}\mathrm{D}_{\text {por }} \\
\AA\end{array}$ & $\begin{array}{l}\mathrm{V}_{\text {пор }} * 10^{3} \\
\text {,cc/g }\end{array}$ & $\begin{array}{l}\eta \\
\%\end{array}$ & $\begin{array}{l}\eta_{\max } \\
, \%\end{array}$ \\
\hline 1 & Sibunit & $1.0-1.6 \mathrm{~mm}$ & 288 & 47.9 & 14.7 & 76.6 & 81.4 \\
\hline 2 & $12.6 \% \mathrm{SiO}_{2} /$ Sibunit & $1.0-1.6 \mathrm{~mm}$ & 216 & 45 & 26.2 & 69.2 & 76.2 \\
\hline 3 & Sibunit & $0.2-0.4 \mathrm{~mm}$ & 324 & 52.2 & 5.5 & 75.1 & 80.6 \\
\hline 4 & CNT & ---- & 250 & ---- & ---- & 86.4 & 89.6 \\
\hline 5 & $4 \% \mathrm{Co} /$ Sibunit & $1.0-1.6 \mathrm{~mm}$ & 264 & 46 & 13.4 & 72.1 & 78.9 \\
\hline 6 & Industrial catalyst & $0.2-0.4 \mathrm{~mm}$ & --- & ---- & ---- & 23.8 & 29.2 \\
\hline 7 & $\begin{array}{c}\text { ASD-1 } \\
\left(\mathrm{Al}_{2} \mathrm{O}_{3} / \mathrm{Al}, \text { pressed }\right)\end{array}$ & $0.1-0.25 \mathrm{~mm}$ & 45.9 & 54.7 & 69.64 & 74.3 & 90.6 \\
\hline 8 & $\begin{array}{c}\text { ASD-1 } \\
\left(\mathrm{Al}_{2} \mathrm{O}_{3} / \mathrm{Al}, \mathrm{HTO} 1 \mathrm{~h}\right)\end{array}$ & $0.5-1 \mathrm{~mm}$ & 41.3 & 37.1 & 49 & 70.2 & 87.1 \\
\hline & $\begin{array}{c}\text { n-hexadecane } \mathrm{C}_{16} \mathrm{H}_{34} \\
\text { n-octacosane } \mathrm{C}_{28} \mathrm{H}_{58}\end{array}$ & & & & & $\begin{array}{l}<2 \\
<1\end{array}$ & $\begin{array}{l}-- \\
--\end{array}$ \\
\hline
\end{tabular}

All samples (except for cracking catalyst) are highly efficient ( $>50 \%$ ) to the MW energyto-heat conversion, while the silica modification of the surface makes a small decrease in the heating efficiency. Hence, it is possible to feed energy to the catalytic system and to 
create thermodynamically preformed conditions owing to the selective MW heating of the catalysts.

GC-MS techniques were used for qualitative and quantitative analysis of the cracking products. It was established that alpha-olefins $\left(\mathrm{C}_{2}-\mathrm{C}_{23}\right)$ and n-alkanes $\left(\mathrm{C}_{2}-\mathrm{C}_{26}\right)$ were the main cracking products under selective MW heating of the used supports and catalysts (Figure 1).

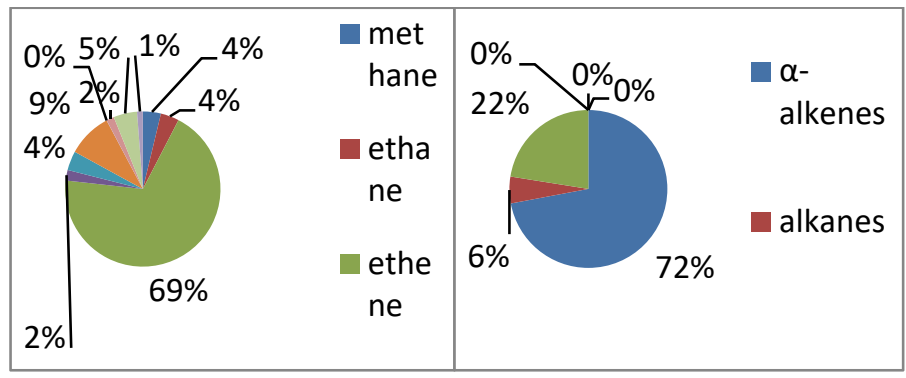

Fig. 1. Composition of products after microwave cracking of n-hexadecane with Sibunit as the MW absorbing catalyst. Left: gaseous products. Right: liquid products

The main gaseous products of the MW cracking over the cracking catalyst were ethylene, propylene and iso-butane, and the main condensed products were iso-alkanes (Figure 2).

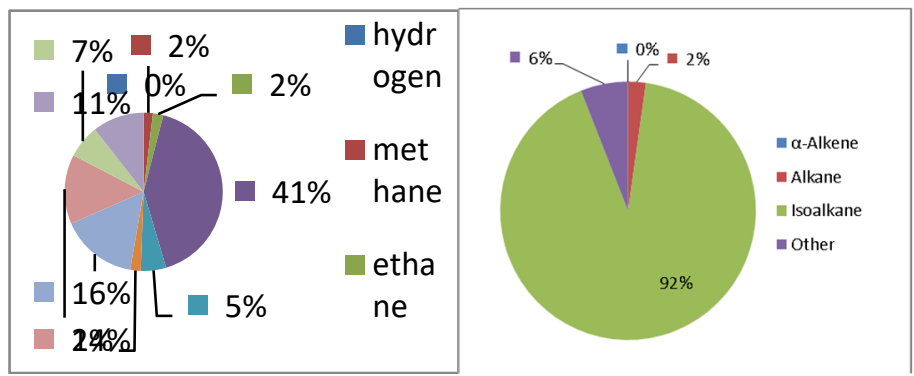

Fig. 2. Composition of products after microwave cracking of n-hexadecane with cracking catalyst as the MW absorbing catalyst. Left: gaseous products. Right: liquid products

Supporting of iron group metals on CM resulted in changes in the structural and group composition of the cracking products and in an increase in the contents of olefin isomers and aromatic hydrocarbons (Figure 3). 


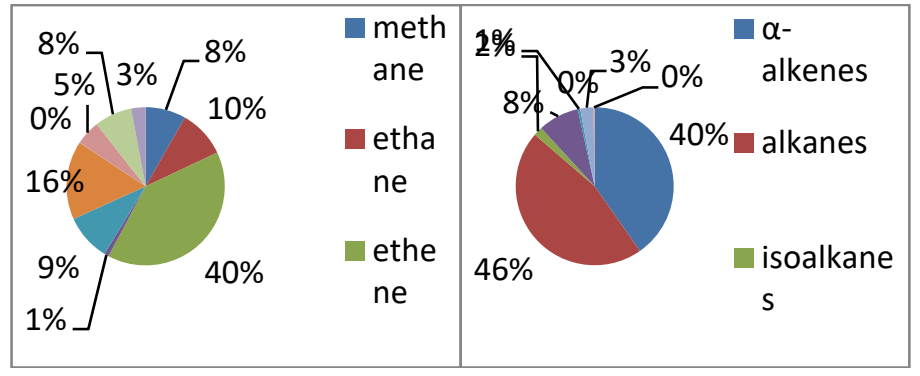

Fig. 3. Composition of products after microwave cracking of n-octacosane with $4 \% \mathrm{Co} /$ Sibunite as the MW absorbing catalyst. Left: gaseous products. Right: liquid products

The quantitative analysis of the products demonstrated that the liquid-phase process is more selective to alpha-olefins at the MW catalytic cracking than at the thermal cracking at the hydrocarbon temperature close to the boiling point at the same reaction time (Table 2).

Table 2. Observed conversion and selectivity to alpha-olefins of high-molecular hydrocarbons over different catalysts

\begin{tabular}{cllllll}
\hline & \multicolumn{3}{c}{ Microwave cracking } & \multicolumn{3}{c}{ Thermal cracking } \\
\cline { 2 - 7 } No. & \multicolumn{1}{c}{$\mathrm{n}$-Hexadecane $\left(\mathrm{C}_{16} \mathrm{H}_{34}\right)$} & \multicolumn{5}{c}{ n-Octacosane $\left(\mathrm{C}_{28} \mathrm{H}_{58}\right)$} \\
\cline { 2 - 7 } & $\begin{array}{c}\text { Conversio } \\
\mathrm{n} \%\end{array}$ & $\begin{array}{c}\text { Selectivity } \\
\%\end{array}$ & $\begin{array}{c}\text { Conversio } \\
\mathrm{n} \%\end{array}$ & $\begin{array}{c}\text { Selectivity } \\
\%\end{array}$ & $\begin{array}{c}\text { Conversio } \\
\mathrm{n} \%\end{array}$ & $\begin{array}{c}\text { Selectivity } \\
\%\end{array}$ \\
\hline 1 & 18.1 & 46.7 & - & - & - & - \\
2 & 15.8 & 63.0 & - & - & - & - \\
3 & 15.9 & 43.0 & 44.1 & 47.7 & 32.5 & 4.61 \\
4 & 9.3 & 45.0 & - & - & & \\
5 & - & - & 30.2 & 40.3 & - & - \\
6 & 16.4 & 16.5 & 63.6 & - & 90.4 & 23.1 \\
7 & 1.5 & 48.4 & 18.7 & 32.7 & - & - \\
8 & 9.4 & 46.9 & - & - & - & - \\
\hline
\end{tabular}

The qualitative product composition was similar to the composition of products of the convectional thermal cracking that indicates the radical-chain mechanism of the MW cracking when the homolytic cleavage of $\mathrm{C}$ bond on the catalyst surface produces two alkyl radicals. An analysis of the results showed that the key factor affecting the conversion in the case of the radical-chain mechanism of the MW cracking is the surface area but not only the chemical composition of the catalyst. Notice that silica modification of the CM surface was shown to suppress spark discharge (usually observed at the MW heating of $\mathrm{CM}$ ); hence, the thermal cleavage of $\mathrm{C}-\mathrm{C}$ bonds on the $\mathrm{CM}$ surface rather than in the plasma discharge contributes the most to the formation of radicals.

\section{Conclusions}

Studies of the MW cracking revealed that the conversion n-hexadecane and n-octacosane could reach 18 and $44 \%$, respectively, over Sibunit and increased up to $63 \%$ in the presence of the cracking catalyst. It was shown that the selectivity to liquid alpha-olefin could be more than $48 \%$ under MW heating of ceramometals. The results obtained demonstrated that the 
selective MW heating during liquid-phase cracking resulted in an increase in the selectivity to alpha-olefins against that of thermal cracking.

\section{Acknowledgement}

The research was supported by RSF (project No. 17-73-30032).

\section{References}

1. George R. Lappin and Joe D. Sauer, Alpha olefins applications handbook, Marcel Dekker, New York, 1989, 454

2. V.A. Bolotov, et al., Journal of Microwave Power and Electromagnetic Energy, 2012, 1, 39-46.

3. Yu. D. Chernousov, et al., Instruments and Experimental Techniques, 2019, 2, 289-294

4. S.F. Tikhov, et al.,, Metal, ceramic and polymeric composites for various uses, INTECH, Croatia, 2011, 195-210

5. V.V. Chesnokov, et al., Composite Structures., 2012, 1, 23-32

6. V.A. Bolotov, et al., 15th International Conference on Microwave and High Frequency Heating (AMPERE2015), 2015, 67 